\title{
Missing JUdGe Tinder
}

\author{
Diane P. WoOD*
}

An experienced judge once made the wry observation that membership on the federal court of appeals is rather like being in an arranged marriage, in a society that forbids divorce. His point was an excellent one: one does not choose one's colleagues, but for however long one wishes to serve as an appellate judge, it is essential to find some modus vivendi that will at minimum create a smooth working relationship with fellow judges and at maximum will lead to deep friendship, productive collaboration, and sound jurisprudence. Particularly for a small court such as the Seventh Circuit Court of Appeals (which has only eleven authorized slots for active judges), the addition of each new judge changes the texture of the entire court, and the loss of a judge leaves a gap that the remaining members of the court feel for years, even as they stand ready to welcome a new colleague.

Judge Tinder served as an active judge on the Seventh Circuit Court of Appeals from December 21, 2007, through February 18, 2015. In so doing, he was one of three who hailed from Indiana; the others were Judge Kenneth F. Ripple of South Bend (now a senior judge), and Judge Michael S. Kanne, of Rensselaer. Judge Tinder himself is a native of Indianapolis, where he has lived all his life, except for the time when he attended undergraduate school and then law school a few miles away at Indiana University's Bloomington campus. He was far from a stranger to his new colleagues on the court of appeals when he arrived, because he spent more than twenty years on the district court bench for the Southern District of Indiana, and before that served as the U.S. Attorney for that district.

We knew enough about Judge Tinder to be delighted that he was about to join us, but we had no way of knowing how quickly and how completely he would become central to the court's culture. The Seventh Circuit, like its sister appellate courts in the federal system and like most intermediate state appellate courts, uses a panel of three judges to decide almost every case. Three to five times a year, the full court will sit en banc to decide a case of major importance, and another ten or so times a year the full court will review a proposed decision that will create a conflict in the circuits, overrule an earlier case, or otherwise take an important step, for possible en banc treatment. But those cases are a drop in the bucket for a court that had 2850 cases commenced in $2015 .{ }^{1}$ Our threejudge panels typically hear six cases in a day of oral argument - and the Seventh Circuit holds oral argument in every case in which there is a lawyer on both sides, with very minor exceptions. The panels change every day during the approximately twenty weeks of regular arguments, as well as the eighteen or so days of "short" arguments, when we give ten minutes a side to nine cases for the day. This means that it takes very little time for a new member of the court to

* Chief Judge, U.S. Court of Appeals for the Seventh Circuit.

1. See Table B-U.S. Courts of Appeals Statistical Tables for the Federal Judiciary (June 30, 2015), U.S. CTS., http://www.uscourts.gov/statistics/table/b/statistical-tables-federaljudiciary/2015/06/30 [https://perma.cc/35PH-62SN] (last visited May 23, 2016).

http://dx.doi.org/10.18060/4806.01115 
take his or her place and begin adding that person's distinctive voice to our deliberations.

When Judge Tinder joined us on the bench and in our conference room, we began to realize what a valuable and altogether wonderful new colleague we had. The ideal judge will keep an open mind with respect to the facts and law of every case; he (in this case) will be thoroughly prepared; he will be courteous not only to the lawyers and parties but also to his fellow judges; he will have a breadth of experience in many areas of the law and thus will be able to contribute to the development of legal doctrine; and he will constantly bear in mind that the litigants before him are real people, who appear either individually or through the companies or other organizations that are the lifeblood of our society. Judge Tinder is all those things and more, and for the seven and a half years of his service on the court of appeals, he inspired us to live up to that example and helped all of us craft well explained, consensus decisions that winners and losers alike could accept.

During the time he was on the Seventh Circuit, Judge Tinder wrote 259 majority opinions (according to Westlaw) for reported, precedential cases. He sat as a panel member on more than a thousand additional cases, if we take into account not only the opinions that wind up in the Federal Reporter, but also the nonprecedential dispositions that make up more than half of our docket now. It is exceedingly difficult to select cases that stand out from this enormous work product, but I will mention just a few.

The first that comes to mind is Bloch v. Frisholtz, ${ }^{2}$ which the court heard en banc in 2009. The question in that case concerned the reach of the Fair Housing Act, ${ }^{3}$ in particular to alleged religious and racial discrimination that occurs after the purchase of a residence; a second, equally important, question was whether the plaintiffs had alleged intentional discrimination, or merely discriminatory impact from a neutral rule. ${ }^{4}$ A panel of the Seventh Circuit, over a dissenting opinion, had held that the complaint failed to state a claim under the Fair Housing Act and that the plaintiffs' evidence showed at most a request for a religious accommodation - relief not required by the statute. ${ }^{5}$ The full court granted rehearing en banc and reversed-unanimously-and explained its thinking in an opinion authored by Judge Tinder. ${ }^{6}$ Judge Tinder's opinion carefully reviewed several different theories under the statute, rejected one of them, but found that two could go forward. ${ }^{7}$ It also took a fresh look at the evidence the plaintiffs presented and, with the benefit of the more thorough arguments presented at the en banc stage, concluded that a rational fact-finder could find intentional discrimination. ${ }^{8}$ The opinion is classic Judge Tinder:

2. 587 F.3d 771 (7th Cir. 2009) (en banc).

3. 42 U.S.C. $\S 3601$ (2012).

4. Bloch, 587 F.3d at 783-87.

5. Id. at 775 .

6. Id. at 772 .

7. See generally id.

8. Id. at 785 . 
careful, thorough, fair to all points of view, and faithful to the procedural and substantive law governing the case.

Another leading case in which Judge Tinder wrote for the court was Sweeney v. Pence, ${ }^{9}$ which considered the legality of Indiana's 2012 Right-to-Work law. Opponents of the legislation brought an action in federal court in which they asserted that the law was preempted by the National Labor Relations Act ${ }^{10}$ and violated both the Federal and the Indiana Constitution. ${ }^{11}$ These were difficult questions, and so it was not surprising that once again, the panel was split 2-1. ${ }^{12}$ Judge Tinder wrote for the majority, explaining its decision to uphold the law. ${ }^{13}$ But, as the dissenting judge on that split, I can confirm without qualification that the tone of the discussion in the majority opinion was at the highest professional level. These are difficult questions, and Judge Tinder approached this one with the same calm, respectful demeanor that is so familiar to all lawyers who saw him at the bench, whether in the Southern District of Indiana or at the Seventh Circuit. The best judges can do when confronted with the hardest cases is to explain as carefully as possible why each one thinks that the law dictates the result the judge favors. That is what Judge Tinder did in Sweeney, because that is what he did in every case.

It would be meaningless to try to pigeonhole him on some kind of political "conservative-to-liberal" spectrum, precisely because it was the law that drove his decisions, not personal preferences. This man, appointed to the district court bench by President Ronald Reagan and to the Seventh Circuit by President George W. Bush, decided in Shan Zhu Qiu v. Holder ${ }^{14}$ that an Immigration Judge had wrongly concluded that a Chinese man who was seeking asylum in the United States lacked a well-founded fear of persecution in China on account of his practice of Falun Gong. As Judge Tinder pointed out, "Falun Gong is strictly prohibited by the Chinese government," and its practitioners face "arrest, detention, and imprisonment." 15 "Asylum," he wrote, "exists to protect people from having to return to a country and conceal their beliefs." " The panel therefore granted Qiu's petition for review and remanded for further proceedings. ${ }^{17}$

In Hendrickson $v$. Cooper ${ }^{18}$ the court had an unfortunately typical prisonviolence case before it. A practically crippled inmate, Vernon Hendrickson, was brutally assaulted in the housing unit by a guard, Cooper. ${ }^{19}$ As Judge Tinder

9. 767 F.3d 654 (7th Cir. 2014).

10. 29 U.S.C. $\S 151$ (2012).

11. Sweeney, 767 F.3d at 657.

12. Id.

13. Id. at $657-71$.

14. 611 F.3d 403 (7th Cir. 2010).

15. Id. at $404,407$.

16. Id. at 408 .

17. Id. at 409 .

18. 589 F.3d 887 (7th Cir. 2009).

19. Id. at 889 . 
described it in the opinion, Cooper "threw his equipment belt out of the way, grabbed Hendrickson, threw him against a wall, slammed him onto the concrete floor, and pressed his knees into Hendrickson's back while another officer cuffed Hendrickson." ${ }^{20}$ A jury found that Cooper had violated Hendrickson's Eighth Amendment rights by using excessive force during that incident; the Seventh Circuit, per Judge Tinder, affirmed the verdict in the prisoner's favor. ${ }^{21}$

Judge Tinder's even-handedness shows through in another case involving criminals, United States $v$. Stacy. ${ }^{22}$ There the question was whether the district court had made a mistake in the criminal trial of a methamphetamine manufacturer (Stacy) by admitting evidence of his prior possession of that drug. ${ }^{23}$ The Federal Rules of Evidence prohibit the use of "prior acts" testimony for the purpose of proving a person's propensity to behave in a certain way; the testimony is permissible for a variety of other purposes. ${ }^{24}$ But this time, Judge Tinder concluded, the prior possession was relevant only to show Stacy's propensity to be mixed up with methamphetamines, and so it should not have come in. ${ }^{25}$ Applying the harmless-error rule, however, the panel concluded that the error did not require reversal. ${ }^{26}$

In every case that came along, we-Judge Tinder's colleagues - knew that we would be the beneficiary of his informed and experienced judgment. We have missed his wise counsel and his cheerful demeanor since he left for good on October 9, 2015, after a brief eight-month stint as a senior judge, undertaken so that he could complete every last bit of work that sat on his desk. But his influence and his example will stay with us always. For all that he did, he has the thanks of the judges, the bar, and the people of the Seventh Circuit.

20. Id. at 890 .

21. See generally id.

22. 769 F.3d 969 (7th Cir. 2014).

23. Id. at 971.

24. Fed. R. Evid. 404(b).

25. Stacy, 769 F.3d at 973-76.

26. Id. 